\title{
Use of Bacillus subtilis D9 to purify coastal aquaculture wastewater and improve grass carp resistance to Vibrio infection
}

\author{
Yalu Shao ${ }^{1,2}$, Hua Zhong ${ }^{1, *}$, Liangkai Wang ${ }^{3}$, Mohammed M. A. Elbashier ${ }^{3}$ \\ ${ }^{1}$ State Key Laboratory of Water Resources and Hydropower Engineering Science, Wuhan University, \\ Wuhan 430072, China \\ ${ }^{2}$ School of Agriculture and Food, The University of Melbourne, Victoria 3010, Australia \\ ${ }^{3}$ College of Agricultural Sciences and Engineering, Hohai University, Nanjing 210098, China
}

\begin{abstract}
In coastal areas of China, high-density aquaculture has caused environmental problems and fish health concerns. Bacillus subtilis D9 is a new strain isolated from coastal soils which could be used in aquaculture to improve the water environment. We investigated the effect of $B$. subtilis D9 on the purification of coastal aquaculture wastewater and the resistance of grass carp Ctenopharyngodon idellus to pathogenic Vibrio infection. Three inoculation levels of $B$. subtilis D9 were used $\left(5.5 \times 10^{7}, 5.5 \times 10^{8}\right.$ and $5.5 \times 10^{9} \mathrm{cfu} \mathrm{ml}^{-1}$ as BD7, BD8 and BD9, respectively), together with sterilized saline water without $B$. subtilis D9 as the Control. B. subtilis D9 at the inoculation level of BD8 showed the best performance with 81, 87, 91, 52 and $86 \%$ removal of $\mathrm{NH}_{4}{ }^{+}-$ $\mathrm{N}, \mathrm{NO}_{3}{ }^{-}-\mathrm{N}$, total nitrogen (TN), $\mathrm{NO}_{2}^{-}-\mathrm{N}$ and turbidity, respectively, after $25 \mathrm{~d}$ of treatment. These values were significantly higher than at the BD7, BD9 and Control levels. Under aeration (AIR) conditions, B. subtilis D9 at the inoculation level of BD8 showed removal efficiency of 93, 91, 95, 76 and $89 \%$, respectively. In contrast it was only $26,29,16,10$ and $57 \%$ in an inactivated bacteria liquid (IBL) treatment. After $22 \mathrm{~d}$ of infection by Vibrio parahaemolyticus, significant differences were found in weight gain, specific growth rate and relative percentage of survival among grass carp grown on AIR, BD8 or IBL wastewater. In summary, B. subtilis D9 with aeration has beneficial effects on the purification of coastal aquaculture wastewater and on the resistance of grass carp to disease caused by $V$. parahaemolyticus.
\end{abstract}

KEY WORDS: Bacillus subtilis D9 - Aeration - Coastal aquaculture wastewater - Purification · Grass carp disease $\cdot$ Ctenopharyngodon idellus $\cdot$ Vibrio parahaemolyticus

\section{INTRODUCTION}

Coastal aquaculture relieves the enormous pressure on ocean resources caused by sea fishing. However, the feasibility, sustainability and potential effectiveness of coastal aquaculture are heavily debated (Di Trapani et al. 2014, Ferreira et al. 2014). The direct discharge of coastal aquaculture wastewater can cause serious deterioration of the marine environment, leading to an increase in pathogenic

*Corresponding author: zhonghua21cn@126.com microbes, the acceleration of pathogenic propagation and eutrophication (Kijjoa et al. 2004, Cho et al. 2019). In recent years, the use of antibiotics in coastal aquaculture has brought serious consequences to humans and aquaculture, such as producing drugresistant strains and causing endogenous infections (Hlongwane et al. 2019, Lulijwa et al. 2019).

Microbial ecological agents have become the most promising substitute for antibiotics due to ecofriendliness, low cost, extensive adaptability and

() The authors 2021. Open Access under Creative Commons by Attribution Licence. Use, distribution and reproduction are unrestricted. Authors and original publication must be credited. 
non-secondary pollution (Martínez Cruz et al. 2012, Oliveira et al. 2012). These preparations contain large amounts of probiotics made of microbial thalli extracted from natural environments (Dong et al. 2010, Akhter et al. 2015). Ai et al. (2013) investigated the effects of microbial ecological agents on the immunocompetence of loach, and found that they increased lysozyme activity and superoxide dismutase activity. In another study, Gelfand et al. (2003) reported that $\mathrm{NH}_{3}$ concentration and $\mathrm{pH}$ value of the water were significantly decreased while the increase of nitrite was inhibited in the presence of microbial ecological agents, resulting in increases in the weights of individual white shrimp and the total yield.

Bacillus subtilis is one of the most commonly used and characteristic microbial ecological agents (Shao et al. 2020). This bacterium mainly exists as a spore, with high stability, stress resistance and antibacterial activity (Pepi et al. 2016, Subtil et al. 2019). B. subtilis can secrete multiple exoenzymes, including protease, lipase, cellulase and soft phospholipase ( $\mathrm{Lu}$ et al. 2018, Cho et al. 2019), which may improve water quality, and can inhibit the growth and reproduction of harmful microbes. Ding et al. (2012) reported removal of $\mathrm{NH}_{3}-\mathrm{N}, \mathrm{NO}_{2}{ }^{-} \mathrm{N}$ and sulfide by $B$. subtilis WH-5 as $80.89,61.72$ and $47.19 \%$, respectively. Similarly, Shao et al. (2016) found that B. subtilis removed $\mathrm{NH}_{4}{ }^{+}-\mathrm{N}, \mathrm{NO}_{2}{ }^{-}-\mathrm{N}$, total nitrogen (TN) and total phosphorus more effectively than water spinach Ipomoea aquatica did, with maximum removal of 68.06, 86.49, 49.96 and $58.82 \%$, respectively.

$B$. subtilis is often used as a feed additive. Its nutritional metabolites such as amino acids and vitamins promote animal growth, improve intestinal microflora and regulate immunity (Liu et al. 2010, Shao et al. 2016). Several studies have reported that $B$. subtilis improved the activities of digestive enzymes, immunity and antioxidative function in white shrimp (Liu et al. 2010, Wang et al. 2019), yellow croaker (Hossain et al. 2015), laying hens (Lee et al. 2014) and tilapia (Zokaeifar et al. 2014). B. subtilis showed no pathogenic and toxic effects on cultured animals, and was easily produced and stored (Chen et al. 2017).

Vibrio parahaemolyticus is found in marine environments and estuaries. It is a key enteropathogenic bacterium and poses a threat in mariculture (Shen et al. 2013, He et al. 2019). Large Vibrio populations in water are a potential threat to aquatic organisms. Hu et al. (2015) reported that cultured grass carp Ctenopharyngodon idellus can be infected with pathogenic vibrios, among which V. parahaemolyticus contributes to the most severe disease outbreaks and fish mortality.
B. subtilis D9 is a newly discovered strain isolated in a coastal area from soil continuously-cropped with Artemisia selengensis infected with Fusarium (95\% of plants) (Chen et al. 2016, 2017). It has the characteristics of $B$. subtilis in terms of metabolic and antibacterial activities (Chen et al. 2017). Effects of $B$. subtilis D9 on wastewater purification and disease resistance of fish in coastal aquaculture have not been reported to date. In this study, the performance of B. subtilis D9 in wastewater treatment and in improving the resistance of grass carp to disease caused by pathogenic $V$. parahaemolyticus was tested with the aim of proving the potential applicability of $B$. subtilis D9 to intensive coastal aquaculture.

\section{MATERIALS AND METHODS}

\subsection{Wastewater samples}

Wastewater samples for the laboratory experiments were collected from a coastal white shrimp pond in Dongtai City, Jiangsu Province, China, and stored under cool conditions $\left(4^{\circ} \mathrm{C}\right)$ before use. Samples were analysed for dissolved oxygen (DO), turbidity and nitrogen in triplicate (mean \pm SD follow). DO was $1.0 \pm 0.1 \mathrm{mg} \mathrm{l}^{-1}$ and turbidity was $7.8 \pm 0.4$ nephelometer turbidity units. $\mathrm{TN}, \mathrm{NH}_{4}{ }^{+}-\mathrm{N}, \mathrm{NO}_{3}{ }^{-}-\mathrm{N}$ and $\mathrm{NO}_{2}{ }^{-} \mathrm{N}$ concentrations were 53.34 \pm 4.67 , $15.90 \pm 2.74,6.84 \pm 1.42$ and $0.77 \pm 0.54 \mathrm{mg} \mathrm{l}^{-1}$, respectively. Based on the nitrogenous forms, $>50 \%$ of TN comprised reduced organic nitrogen.

\subsection{Microbe strains and culture}

Bacillus subtilis strain D9 was isolated in a coastal area from soil continuously-cropped with Artemisia selengensis infected with Fusarium (Chen et al. 2016, 2017) and was stored in the China General Microbiological Culture Collection Center (CGMCCC) (under accession no. 9170). The selected B. subtilis strain was cultured for enrichment at $37^{\circ} \mathrm{C}$ for $24 \mathrm{~h}$ in nutrient broth which contained peptone $\left(10 \mathrm{~g} \mathrm{l}^{-1}\right)$, beef extract $\left(3 \mathrm{~g} \mathrm{l}^{-1}\right)$ and $\mathrm{NaCl}\left(5 \mathrm{gl}^{-1}\right), \mathrm{pH} 7.2-7.5$, and autoclaved at $121^{\circ} \mathrm{C}$ for $30 \mathrm{~min}$. Bacterial cell density of the incubation solution was adjusted to $5.5 \times 10^{11} \mathrm{cfu} \mathrm{ml}^{-1}$. The inactivated bacteria liquid (IBL) of $B$. subtilis D9 was made by autoclaving it at $110-125^{\circ} \mathrm{C}$ for $30 \mathrm{~min}$.

The Vibrio parahaemolyticus strain (accession no. 43305) was provided by the CGMCCC and cultured with a bacterial cell density of $4.65 \times 10^{7} \mathrm{cfu} \mathrm{ml}^{-1}$ in the incubation solution. 


\subsection{Experimental design}

\subsubsection{Wastewater purification}

The experiments were conducted in a greenhouse at temperatures of $29-40^{\circ} \mathrm{C}$ (day) and $15-30^{\circ} \mathrm{C}$ (night) in Nanjing, China, for $25 \mathrm{~d}$. Twelve glass jars of $0.1 \mathrm{~m}^{3}$ containing $10 \mathrm{l}$ of wastewater were used in the experiments with 4 treatments. In each treatment, $100 \mathrm{ml}$ of B. subtilis D9 solution with $5.5 \times 10^{9}, 5.5 \times 10^{10}$ and $5.5 \times 10^{11} \mathrm{cfu} \mathrm{ml}^{-1}$ and sterilized saline water were added to the jars and mixed well. This yielded $B$. subtilis D9 concentrations of ca. $5.5 \times 10^{7}$ (BD7), $5.5 \times 10^{8}$ (BD8) and $5.5 \times 10^{9} \mathrm{cfu} \mathrm{ml}^{-1}$ (BD9), together with the Control. For the wastewater purification test, each treatment $(\mathrm{n}=3)$, was intermittently shaken without additional aeration. The quality indices for $\mathrm{NH}_{4}{ }^{+}-\mathrm{N}$, $\mathrm{NO}_{3}{ }^{-}-\mathrm{N}, \mathrm{TN}, \mathrm{NO}_{2}{ }^{-}-\mathrm{N}$ and turbidity for wastewater were determined $1,2,4,6,8,10,15,20$ and $25 \mathrm{~d}$ after the initial inoculation. The amount of B. subtilis D9 in the wastewater was measured for the $B$. subtilis D9 inoculation treatments on Day 25. The \% removal of pollutants $(Y)$ was calculated as follows:

$$
Y=\left(C_{0}-C_{t}\right) / C_{0} \times 100
$$

where $C_{t}$ and $C_{0}$ are the final and initial pollutant concentrations, respectively, and $t$ is the duration of the experiment in days.

\subsubsection{Aeration (AIR) and IBL treatment}

B. subtilis D9 solution (100 ml) and IBL with $5.5 \times$ $10^{11} \mathrm{cfu} \mathrm{ml}^{-1}$ together with sterilized saline water was added into $0.1 \mathrm{~m}^{3}$ jars containing $10 \mathrm{l}$ of wastewater and mixed well. Air was supplied to the jars using a four holes high-power aeration pump at a flow rate of $2.01 \mathrm{~min}^{-1}$, and the DO concentration was maintained at 5-6 $\mathrm{mg} \mathrm{l}^{-1}$ for AIR and IBL treatments as well as for Control treatments to which no $B$. subtilis D9 was added. Each treatment was performed in 3 replicates. The experimental process and conditions were the same as those described in Section 2.3.1. $\mathrm{NH}_{4}{ }^{+}-\mathrm{N}$, $\mathrm{NO}_{3}{ }^{-}-\mathrm{N}, \mathrm{TN}, \mathrm{NO}_{2}{ }^{-}-\mathrm{N}$ and turbidity were determined on Days $1,2,4,6,8,10,15,20$ and 25 after inoculation.

\subsubsection{Grass carp infection experiment}

Grass carps $(\mathrm{n}=240)$ with an average $( \pm \mathrm{SD})$ length and weight of $13.56 \pm 1.25 \mathrm{~cm}$ and $10.67 \pm 0.97 \mathrm{~g}$ were selected to be acclimatized for $7 \mathrm{~d}$ in fish jars. The fish were divided into 4 experimental groups including Control, BD8, AIR and IBL as described in the above experiments (Control and BD8 treated as in Section 2.3.1; AIR and IBL treated as in Section 2.3.2). One $\mathrm{ml}$ of $V$. parahaemolyticus with bacterial colonies of $4.65 \times 10^{7} \mathrm{cfu} \mathrm{ml}^{-1}$ was added into grass carp culture jars of $0.7 \mathrm{~m}^{3}$ containing $100 \mathrm{l}$ of aquaculture wastewater. Each treatment had 3 replicates, and the experiment lasted $22 \mathrm{~d}$. Food was provided at 09:00 and 17:00 h every day, and 5\% of water (treated for $25 \mathrm{~d}$ ) was supplemented every $2 \mathrm{~d}$ to top up the volume. The feeding quantity was $5-7 \%$ of the fish body weight. Weight and mortality of the grass carp were recorded every $2 \mathrm{~d}$. Percentage of weight gain (PWG) (Hao et al. 2014), specific growth rate (SGR) (Liu et al. 2017) and relative percentage of survival (RPS) (Marinho-Soriano et al. 2011) were calculated with the following equations:

$$
\begin{gathered}
\mathrm{PWG}=\left[\left(W_{t}-W_{0}\right) / W_{0}\right] \times 100 \\
\mathrm{SGR}=\left[\left(\ln W_{t}-\ln W_{0}\right) / W_{0}\right] \times 100 \\
\mathrm{RPS}=\left[1-\left(P_{t}-P_{\mathrm{c}}\right) / W_{0}\right] \times 100
\end{gathered}
$$

where $W_{t}$ and $W_{0}$ are the final and initial fish weight, respectively; $t$ is the experimental duration in days; $P_{t}$ is the percentage of fish mortality in treated groups; and $P_{C}$ is the percentage of fish mortality in the Control group. The populations of $V$. parahaemolyticus were determined for each experimental group on Day 22 post infection.

\subsubsection{In situ aquaculture pond water purification}

In situ purification of intensive white shrimp pond water was conducted at an aquaculture farm located near the coast in Dongtai City, Jiangsu Province, to compare the purifying effects of $B$. subtilis D9 with EM, a commercial aquaculture water purification agent. Three treatments were set up as follows: (1) Control: no EM or BD9 in the aquaculture pond; (2) EM: EM at the concentration of about $5.5 \times 10^{8} \mathrm{cfu}$ $\mathrm{ml}^{-1}$ in the pond; and (3) BD8: B. subtilis D9 at the concentration of about $5.5 \times 10^{8} \mathrm{cfu} \mathrm{ml}^{-1}$ in the pond. $6670 \mathrm{ml}$ of $\mathrm{EM}$ or B. subtilis D9 containing $5.5 \times$ $10^{11} \mathrm{cfu} \mathrm{ml} \mathrm{m}^{-1}$ was used per $6.67 \mathrm{~m}^{2}$ of each pond at about $1.0 \mathrm{~m}$ depth; they were mixed with aquaculture water at a volume ratio of 1:1000 and uniformly applied to the breeding pond via an electric spray. Water samples at a depth of $60 \mathrm{~cm}$ were taken in 3 different places on Day 25 of each treatment. Numerical values of the water quality indicators for $\mathrm{NH}_{4}{ }^{+}-\mathrm{N}$, $\mathrm{NO}_{3}{ }^{-}-\mathrm{N}, \mathrm{TN}, \mathrm{NO}_{2}{ }^{-}-\mathrm{N}$ and turbidity were determined and compared. 


\subsubsection{Water quality indicators and biomass}

The biomass of B. subtilis D9 and V. parahaemolyticus was determined using the plate count method (Yang et al. 2012). Nessler's reagent spectrophotometry was used for $\mathrm{NH}_{4}{ }^{+}-\mathrm{N}$ determination (Yu 2015). N-(1naphthyl) ethylene diamine dihydrochloride spectrophotometric method was used for $\mathrm{NO}_{2}{ }^{-}-\mathrm{N}$ determination (Liu et al. 2017). A YSI 550A portable DO meter was used to measure DO (Yang et al. 2012), and UV spectrophotometry was applied to determine $\mathrm{NO}_{3}{ }^{-}-\mathrm{N}$ (Yang et al. 2012). TN was measured with alkaline potassium persulfate digestion UV spectrophotometry (Li et al. 2009), and turbidity was determined with a WGZ-1B portable turbidity meter (Yang et al. 2012).

\subsection{Statistical analysis}

One-way ANOVA followed by Tukey's post hoc test was used to compare water quality parameters in the B. subtilis D9-based wastewater purification experiment, as well as fish weight and mortality indicators in the infection experiments among treatments and the Control groups. Paired-sample $t$-tests were used to compare AIR and IBL treatments in the water quality experiments. Prior to statistical analysis, raw data were assessed for normality of distribution and homogeneity of variance using Kolmogorov-Smirnov and Levene's tests, respectively (Zar 2010). Data are presented as means $\pm \mathrm{SD}(\mathrm{n}=3)$. All statistics were conducted in SPSS 19.0. Results were considered statistically significant when $\mathrm{p}<0.05$. Figures were drawn with Origin Pro 8.0 scientific graphing and data analysis software.

\section{RESULTS}

\subsection{Effects of the concentration of Bacillus subtilis D9 on wastewater purification}

Initially, on the first day, concentrations of $\mathrm{NH}_{4}{ }^{+}-\mathrm{N}$, $\mathrm{NO}_{3}{ }^{-}-\mathrm{N}$ and TN in the BD7, BD8 and BD9 treatments increased after B. subtilis D9 was added, whereas they did not change significantly in the Control treatment (Fig. 1). Generally, however, the concentrations of $\mathrm{NH}_{4}{ }^{+}-\mathrm{N}, \mathrm{NO}_{3}{ }^{-}-\mathrm{N}, \mathrm{TN}, \mathrm{NO}_{2}^{-}-\mathrm{N}$ and turbidity decreased over time, reached a stable value on Day 8 and then continued to decrease slowly (Fig. 1a-e). DO in all B. subtilis D9 treatments showed a decreasing trend at the beginning (Fig. 1f) and a rapid increase after Day 8. DO values in the BD8 treatment were significantly higher than in the other BD (Tukey's test, $\mathrm{p}=0.013$ ) and Control (Tukey's test, $\mathrm{p}=$ 0.010) treatments after Day 10.

Percent removal of $\mathrm{NH}_{4}{ }^{+}-\mathrm{N}, \mathrm{NO}_{3}{ }^{-}-\mathrm{N}, \mathrm{TN}, \mathrm{NO}_{2}{ }^{-} \mathrm{N}$ and turbidity was calculated on Days 8 and 25 (Table 1). Results showed that the BD8 treatment had the best removal efficiencies, of $81,87,91,52$ and $86 \%$ for $\mathrm{NH}_{4}{ }^{+}-\mathrm{N}, \mathrm{NO}_{3}{ }^{-}-\mathrm{N}, \mathrm{TN}, \mathrm{NO}_{2}{ }^{-}-\mathrm{N}$ and turbidity, respectively, on Day 25; significantly higher than those in the other B. subtilis D9 treatments (Tukey's test, $\mathrm{p}=$ 0.010) and Control (Tukey's test, $\mathrm{p}=0.008$ ) (Table 1). On Day 25, DO in the BD8 treatment reached $3.47 \mathrm{mg}$ $1^{-1}$, which was significantly higher than in the other $B$. subtilis D9 treatments (Tukey's test, $\mathrm{p}=0.018$ ) and the Control (Tukey's test, $\mathrm{p}=0.021$ ) (Table 1). Furthermore, the biomass of viable bacteria in BD8 and BD9 treatments ranged between $1.4 \times 10^{8}$ and $4.9 \times 10^{8} \mathrm{cfu}$ $\mathrm{ml}^{-1}$ on Day 25, which was significantly reduced $(t-$ tests, $\mathrm{p}<0.05$ ) compared to those in the initial inoculation, while the viable bacteria in the BD7 treatment were increased ( $t$-tests, p < 0.05) (Fig. 2).

\subsection{Effects of AIR and IBL of BD8 on wastewater quality}

Concentrations of $\mathrm{NH}_{4}{ }^{+}-\mathrm{N}, \mathrm{NO}_{3}{ }^{-}-\mathrm{N}$ and $\mathrm{TN}$ in the AIR, IBL and Control treatments initially increased after bacterium injection (Fig. 3). After $1 \mathrm{~d}$, the concentrations of $\mathrm{NH}_{4}{ }^{+}-\mathrm{N}, \mathrm{NO}_{3}{ }^{-}-\mathrm{N}, \mathrm{TN}, \mathrm{NO}_{2}{ }^{-}-\mathrm{N}$ and turbidity in wastewater in the treatments decreased gradually with the reaction time, reached a stable value after 6-10 d, and then decreased again slowly. On Day 8, \% removal of $\mathrm{NH}_{4}{ }^{+}-\mathrm{N}, \mathrm{NO}_{3}{ }^{-}-\mathrm{N}, \mathrm{TN}, \mathrm{NO}_{2}{ }^{-}-$ $\mathrm{N}$ and turbidity in the AIR treatment reached 93, 91, 95,76 and $89 \%$, respectively, which was much higher $(t$-tests, p < 0.05) than in the IBL treatment $(9,5,6,10$ and $27 \%$, respectively) and Control treatment $(21,28$, 30,29 and $36 \%$, respectively) (Table 2). On Day 25, the \% removal of all pollutants in the AIR treatment remained almost unchanged ( $t$-tests, $p>0.05$ ) compared to Day 8. However, the \% removal in IBL and Control groups on Day 25 was significantly higher $(t-$ tests, $\mathrm{p}<0.05$ ) than those on Day 8 except for $\mathrm{NO}_{2}{ }^{-}-\mathrm{N}$. Compared with the BD8 data in Table 1, the relevant removal rates of pollutants were ranked as AIR $>$ BD8 $>$ Control $>$ IBL on Days 8 and 25 ( $t$-tests, $\mathrm{p}<0.05)$.

\subsection{Grass carp infection experiment}

The final weight, weight gain, PWG and SGR of grass carp were significantly higher in all groups and 

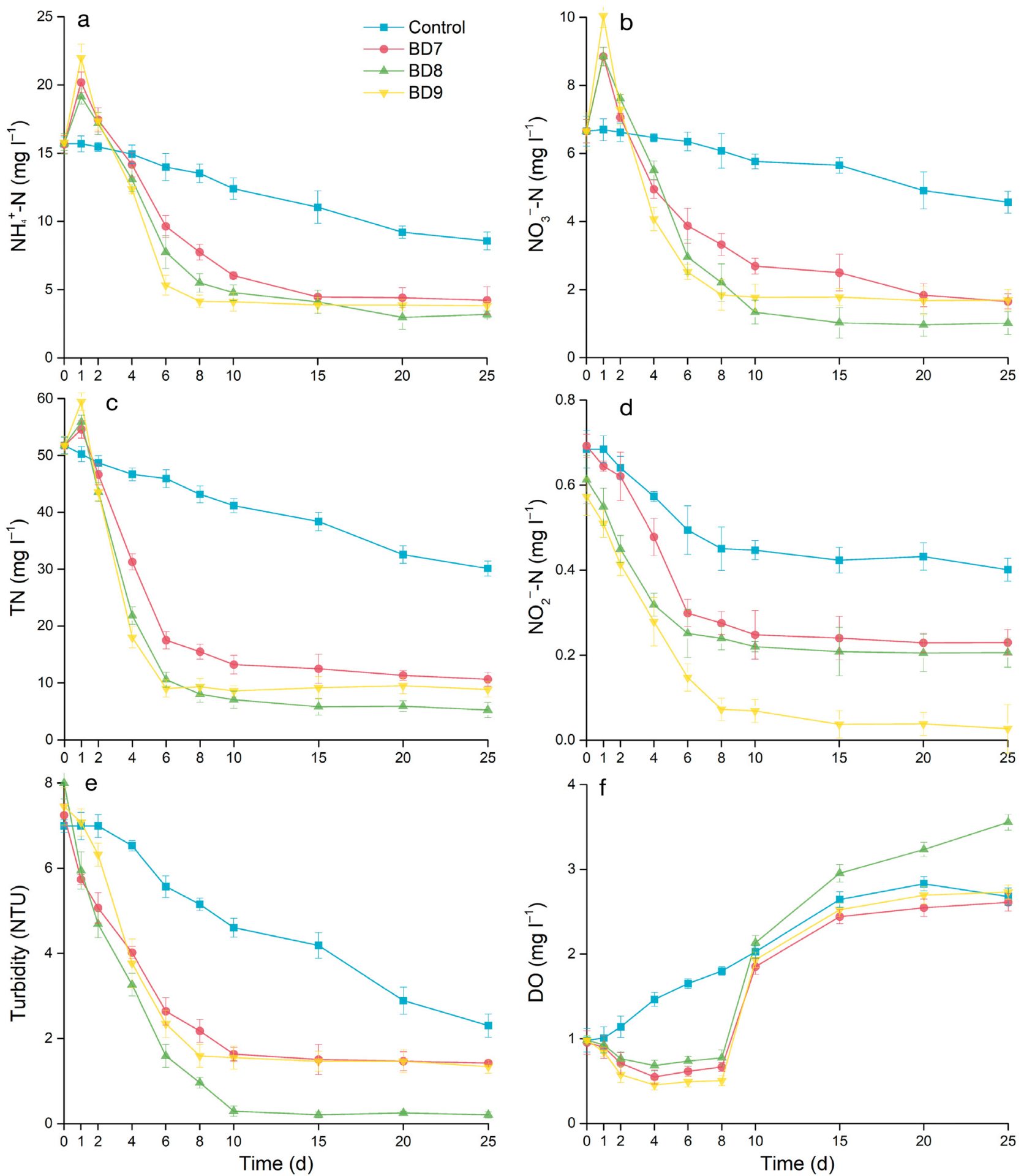

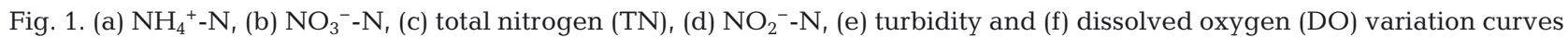
under different treatments. Vertical bars represent \pm SD of the means $(n=3)$. BD7/BD8/BD9: inoculation levels of Bacillus subtilis D9 at $5.5 \times 10^{7} / 5.5 \times 10^{8} / 5.5 \times 10^{9} \mathrm{cfu} \mathrm{ml}^{-1}$

ranked as AIR > BD8 > Control > IBL (Table 3). The RPS of grass carp was higher in the AIR group (ANOVA, Tukey's test, $F_{3,8}=12.528, \mathrm{p}=0.001$ ) com- pared to the BD8 group (ANOVA, Tukey's test, $F_{3,8}=$ 8.517, $\mathrm{p}=0.008$ ) and IBL group (ANOVA, Tukey's test, $F_{3,8}=6.814, \mathrm{p}=0.013$ ). The final weight, weight 
Table 1. Effect of Bacillus subtilis D9 inoculum on the removal of nitrogenous pollutants, turbidity and dissolved oxygen (DO) concentration in wastewater after 8 and $25 \mathrm{~d}$. Data are means \pm SD. BD7/BD8/BD9: inoculation levels of B. subtilis D9 at 5.5 $\times$ $10^{7} / 5.5 \times 10^{8} / 5.5 \times 10^{9} \mathrm{cfu} \mathrm{ml}^{-1}$; TN: total nitrogen. Within columns, means with the same superscript letters are not significantly different (Tukey's post hoc test, $p>0.05$ )

\begin{tabular}{|c|c|c|c|c|c|c|c|}
\hline \multirow{2}{*}{ Day } & \multirow{2}{*}{ Treatment } & & & \multirow{2}{*}{$\begin{array}{c}\text { Removal (\%) } \\
\text { TN }\end{array}$} & \multirow[b]{2}{*}{$\mathrm{NO}_{2}{ }^{-}-\mathrm{N}$} & \multirow[b]{2}{*}{ Turbidity } & \multirow{2}{*}{$\begin{array}{c}\mathrm{DO} \\
\left(\mathrm{mg} \mathrm{l}^{-1}\right)\end{array}$} \\
\hline & & $\mathrm{NH}_{4}{ }^{+}-\mathrm{N}$ & $\mathrm{NO}_{3}{ }^{-}-\mathrm{N}$ & & & & \\
\hline \multirow[t]{4}{*}{8} & Control & $14 \pm 0.6^{\mathrm{c}}$ & $18 \pm 0.2^{\mathrm{c}}$ & $20 \pm 0.1^{\mathrm{c}}$ & $21 \pm 0.5^{\mathrm{c}}$ & $31 \pm 0.4^{\mathrm{c}}$ & $1.81 \pm 0.07^{a}$ \\
\hline & BD7 & $66 \pm 0.7^{b}$ & $61 \pm 0.5^{\mathrm{b}}$ & $74 \pm 0.8^{b}$ & $39 \pm 0.3^{\mathrm{b}}$ & $69 \pm 0.8^{b}$ & $0.79 \pm 0.03^{c}$ \\
\hline & BD8 & $70 \pm 0.9^{\mathrm{ab}}$ & $81 \pm 0.8^{\mathrm{a}}$ & $86 \pm 0.7^{a}$ & $48 \pm 0.3^{\mathrm{a}}$ & $84 \pm 0.9^{a}$ & $0.87 \pm 0.05^{b}$ \\
\hline & BD9 & $76 \pm 0.8^{\mathrm{a}}$ & $75 \pm 0.3^{\mathrm{a}}$ & $83 \pm 0.6^{\mathrm{ab}}$ & $36 \pm 0.4^{\mathrm{b}}$ & $68 \pm 0.5^{\mathrm{b}}$ & $0.73 \pm 0.08^{c}$ \\
\hline \multirow[t]{4}{*}{25} & Control & $45 \pm 0.7^{\mathrm{c}}$ & $40 \pm 0.3^{\mathrm{c}}$ & $45 \pm 0.5^{\mathrm{b}}$ & $27 \pm 0.4^{\mathrm{c}}$ & $67 \pm 0.7^{\mathrm{c}}$ & $2.67 \pm 0.21^{b}$ \\
\hline & BD7 & $75 \pm 0.8^{\mathrm{abc}}$ & $78 \pm 0.9^{b}$ & $80 \pm 0.7^{a}$ & $42 \pm 0.4^{\mathrm{b}}$ & $73 \pm 0.8^{b}$ & $2.68 \pm 0.18^{b}$ \\
\hline & BD8 & $81 \pm 0.7^{a}$ & $87 \pm 1.2^{\mathrm{a}}$ & $91 \pm 1.3^{\mathrm{a}}$ & $52 \pm 0.6^{\mathrm{a}}$ & $86 \pm 0.9^{a}$ & $3.47 \pm 0.33^{a}$ \\
\hline & BD9 & $78 \pm 0.9^{\mathrm{ab}}$ & $78 \pm 0.6^{b}$ & $83 \pm 0.9^{a}$ & $39 \pm 0.4^{\mathrm{bc}}$ & $69 \pm 0.4^{\mathrm{c}}$ & $2.78 \pm 0.22^{b}$ \\
\hline
\end{tabular}

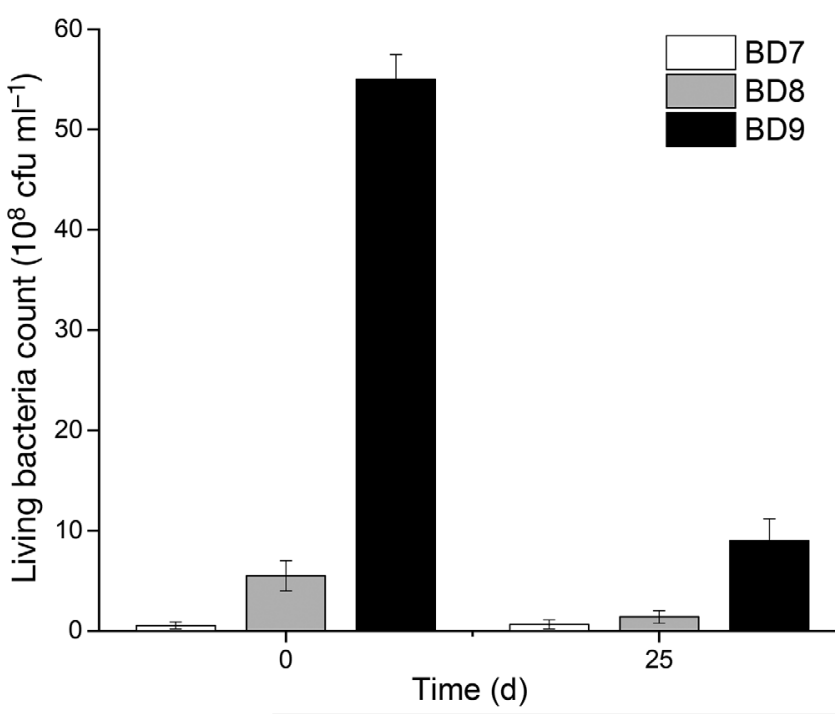

Fig. 2. Biomass of viable Bacillus subtilis D9 in different treatments on Days 0 and 25. Vertical bars represent \pm SD of the means $(\mathrm{n}=3)$. BD7/BD8/BD9: inoculation levels of Bacillus subtilis D9 at $5.5 \times 10^{7} / 5.5 \times 10^{8} / 5.5 \times 10^{9} \mathrm{cfu} \mathrm{ml}^{-1}$

gain, PWG and SGR of grass carp in the IBL group were lower than those in the Control group, but the differences were not significant ( $t$-tests, $\mathrm{p}>0.05)$. The RPS value in the IBL group (ANOVA, Tukey's test, $F_{3,8}=13.927, \mathrm{p}=0.001$ ) was negative, and was significantly lower than those in the BD8 group (ANOVA, Tukey's test, $F_{3,8}=9.927, \mathrm{p}=0.004$ ) and the Control group (ANOVA, Tukey's test, $F_{3,8}=$ 8.152, $\mathrm{p}=0.010$ ).

\subsection{In situ aquaculture pond water purification}

Spraying of $B$. subtilis D9 into the shrimp pond at $5.5 \times 10^{8} \mathrm{cfu} \mathrm{ml}^{-1}$ significantly lowered the concen- trations of $\mathrm{NH}_{4}{ }^{+}-\mathrm{N}, \mathrm{NO}_{3}{ }^{-}-\mathrm{N}, \mathrm{TN}, \mathrm{NO}_{2}{ }^{-}-\mathrm{N}$ and turbidity compared with the Control and EM treatments ( $\mathrm{p}<0.05$ ) on Day 25 (Table 4). Percent removal of $\mathrm{NH}_{4}{ }^{+}-\mathrm{N}, \mathrm{NO}_{3}{ }^{-}-\mathrm{N}, \mathrm{TN}, \mathrm{NO}_{2}{ }^{-}-\mathrm{N}$ and turbidity in the BD8 treatment reached 81, 87, 85, 62 and 82\%, respectively, which was significantly higher than that in EM and Control treatments.

\section{DISCUSSION}

In the present study, the concentrations of $\mathrm{NH}_{4}{ }^{+}-\mathrm{N}$, $\mathrm{NO}_{3}{ }^{-}-\mathrm{N}$ and $\mathrm{TN}$ in the Bacillus subtilis D9 treatments increased during the first day after bacterium injection to wastewater, possibly due to short-term accumulation of nitrogen from the transformation of organic biomass in the wastewater reaction system. This result is consistent with reports by Boopathy et al. (2015) and Chen et al. (2017), who used other microbial agents for wastewater treatment. Our results indicate that $B$. subtilis D9 can effectively reduce the concentrations of $\mathrm{NH}_{4}{ }^{+}-\mathrm{N}, \mathrm{NO}_{3}{ }^{-}-\mathrm{N}, \mathrm{TN}$, $\mathrm{NO}_{2}{ }^{-}-\mathrm{N}$ and turbidity in wastewater, similarly to other microbial ecological agents (Lu et al. 2012). The highest removal of $\mathrm{NH}_{4}{ }^{+}-\mathrm{N}, \mathrm{NO}_{3}{ }^{-}-\mathrm{N}, \mathrm{TN}, \mathrm{NO}_{2}{ }^{-}-$ $\mathrm{N}$ and reduction in turbidity were recorded in the BD8 group. The decrease in various forms of $\mathrm{N}$ could be attributed to $B$. subtilis D9 degrading $\mathrm{NH}_{4}{ }^{+}-\mathrm{N}$, $\mathrm{NO}_{3}{ }^{-} \mathrm{N}$ and $\mathrm{NO}_{2}{ }^{-}-\mathrm{N}$ through nitrification and denitrification and possibly assimilating $\mathrm{NH}_{4}{ }^{+}-\mathrm{N}, \mathrm{NO}_{2}{ }^{-} \mathrm{N}$ and $\mathrm{NO}_{3}{ }^{-} \mathrm{N}$ as cell components during the process (Chen et al. 2017, Yun et al. 2019). The reduction of turbidity in the $B$. subtilis D9 treatments could be attributed to flocculation and microbial decomposition (Lu et al. 2018, Cho et al. 2019). DO in the 3 BD treatments decreased during the first $4 \mathrm{~d}$, which differed from the Control treatment. This could be due 

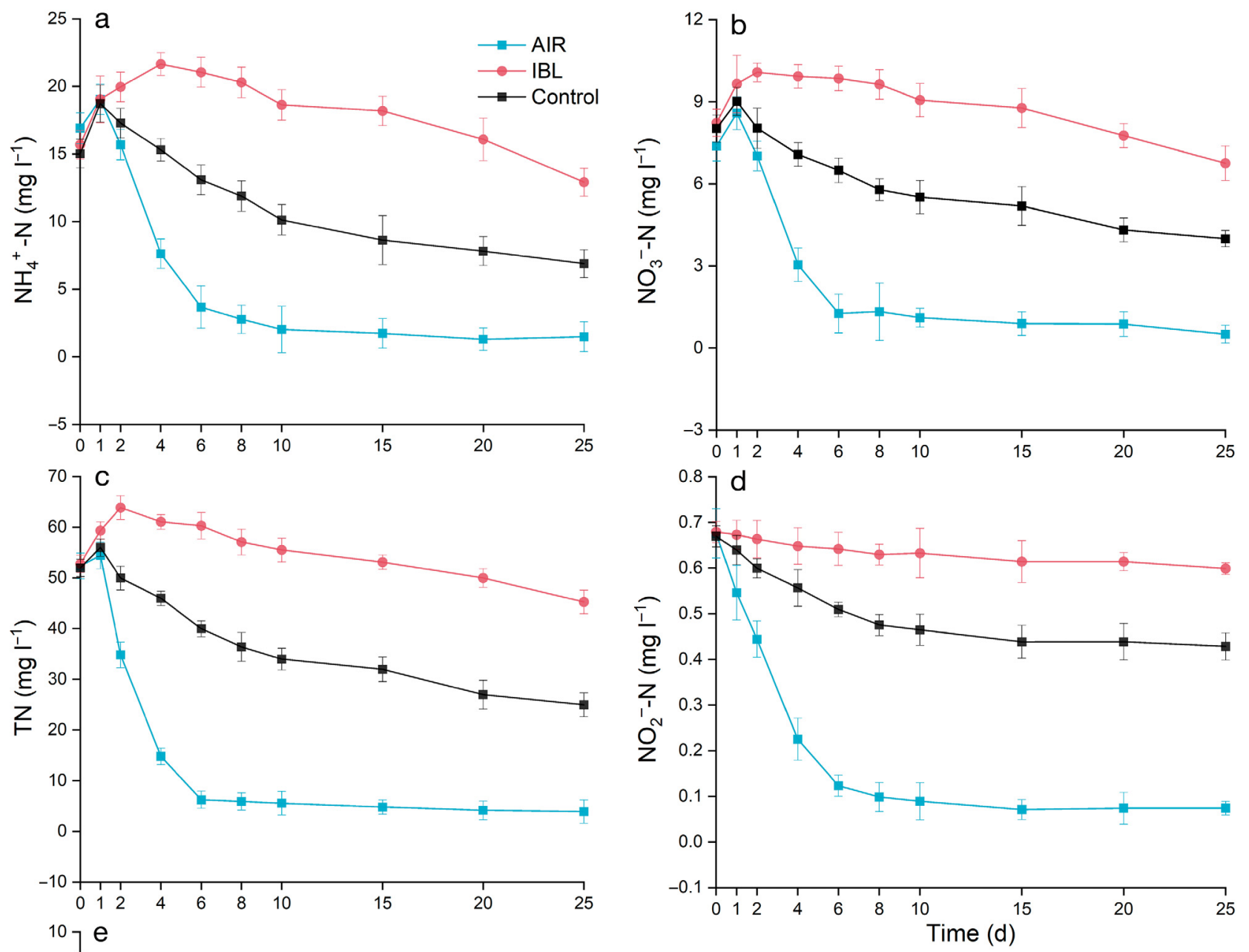

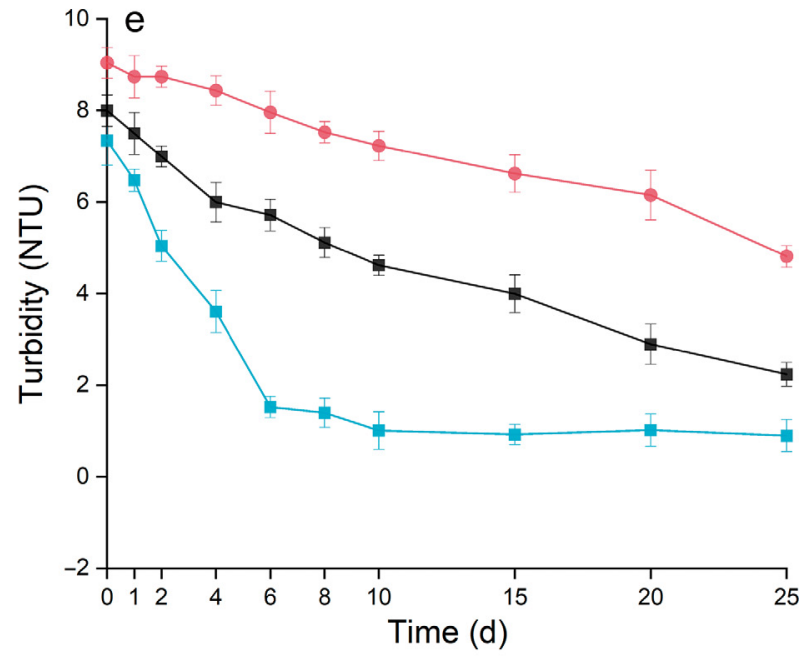

to the fact that $B$. subtilis is a Gram-positive, aerobic bacterium that consumes a large amount of oxygen (Lu et al. 2012). The increase in DO after 4-8 d may be due to the decomposition of a high amount of reduced organic substances and the reduction of viable bacteria in wastewater. Observed removal of $\mathrm{NO}_{2}{ }^{-}-\mathrm{N}$ was lower, indicating that $\mathrm{NO}_{2}{ }^{-}-\mathrm{N}$ oxidation
Fig. 3. (a) $\mathrm{NH}_{4}{ }^{+}-\mathrm{N}$, (b) $\mathrm{NO}_{3}{ }^{-}-\mathrm{N}$, (c) total nitrogen (TN), (d) $\mathrm{NO}_{2}^{-}-\mathrm{N}$ and (e) turbidity variation curves under aeration (AIR), inactivated bacteria liquid (IBL) and Control treatments. Vertical bars represent \pm SD of the means $(n=3)$

caused by $B$. subtilis D9 was impeded at a low concentration of DO (Ding et al. 2012). Removal of $\mathrm{NH}_{4}{ }^{+}-$ $\mathrm{N}, \mathrm{NO}_{3}{ }^{-}-\mathrm{N}, \mathrm{TN}, \mathrm{NO}_{2}{ }^{-}-\mathrm{N}$ and reduction of turbidity in the AIR treatment were significantly higher than in the IBL treatment (Table 2), suggesting that the bacterial activity of $B$. subtilis D9 is key for wastewater purification. Similar findings of the effect of $B$. sub- 
Table 2. Removal of nitrogenous pollutants and turbidity under aeration (AIR) and inactivated bacteria liquid (IBL) treatments with inoculation levels of Bacillus subtilis D9 at $5.5 \times 10^{8} \mathrm{cfu} \mathrm{ml}^{-1}$ (BD8) after 8 and $25 \mathrm{~d}$. Data are means $\pm \mathrm{SD}$. Within columns, means with the same superscript letters are not significantly different (Tukey's post hoc test, $\mathrm{p}>0.05$ )

\begin{tabular}{|c|c|c|c|c|c|c|}
\hline \multirow{2}{*}{ Time } & \multirow{2}{*}{ Treatment } & & & Removal (\%) & 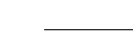 & \multirow[b]{2}{*}{ Turbidity } \\
\hline & & $\mathrm{NH}_{4}^{+}-\mathrm{N}$ & $\mathrm{NO}_{3}{ }^{-}-\mathrm{N}$ & $\mathrm{TN}$ & $\mathrm{NO}_{2}{ }^{-}-\mathrm{N}$ & \\
\hline \multirow[t]{3}{*}{$8 d$} & AIR & $93 \pm 1.2^{\mathrm{a}}$ & $91 \pm 1.1^{\mathrm{a}}$ & $95 \pm 1.2^{\mathrm{a}}$ & $76 \pm 0.6^{\mathrm{a}}$ & $89 \pm 0.8^{a}$ \\
\hline & IBL & $9 \pm 0.5^{b}$ & $5 \pm 0.3^{b}$ & $6 \pm 0.2^{\mathrm{b}}$ & $10 \pm 0.1^{\mathrm{b}}$ & $27 \pm 0.7^{b}$ \\
\hline & Control & $21 \pm 0.4^{\mathrm{c}}$ & $28 \pm 0.5^{\mathrm{c}}$ & $30 \pm 0.6^{c}$ & $29 \pm 0.8^{\mathrm{c}}$ & $36 \pm 0.8^{c}$ \\
\hline \multirow[t]{3}{*}{$25 \mathrm{~d}$} & AIR & $94 \pm 1.5^{\mathrm{a}}$ & $92 \pm 1.3^{\mathrm{a}}$ & $96 \pm 1.5^{\mathrm{a}}$ & $79 \pm 0.8^{\mathrm{a}}$ & $91 \pm 0.9^{a}$ \\
\hline & IBL & $19 \pm 0.5^{b}$ & $19 \pm 0.3^{b}$ & $16 \pm 0.2^{\mathrm{cb}}$ & $11 \pm 0.1^{b}$ & $57 \pm 0.7^{b}$ \\
\hline & Control & $54 \pm 0.5^{c}$ & $49 \pm 0.8^{\mathrm{c}}$ & $52 \pm 0.6^{c}$ & $36 \pm 0.4^{\mathrm{c}}$ & $72 \pm 0.7^{\mathrm{c}}$ \\
\hline
\end{tabular}

and RPS of grass carp were significantly higher, and the populations of pathogenic Vibrio parahaemolyticus were reduced compared to the BD8, Control and IBL groups. Our results are in agreement with reports by Liu et al. (2010) and Kuebutornye et al. (2019), who reported that B. subtilis could enhance disease resistance, reduce stress, improve gastrointestinal morphology and promote growth of cultured fishes. Shen et al. (2013) observed that $B$. subtilis in diets could promote the growth of black carp and decrease the feed conversion ratio.

tilis on lightly polluted water were observed by Chen \& $\mathrm{Hu}$ (2011), who reported that the removal of $\mathrm{NH}_{4}{ }^{+}-\mathrm{N}$ and $\mathrm{NO}_{2}{ }^{-}-\mathrm{N}$ reached 96.7 and $82.0 \%$, respectively, $9 \mathrm{~d}$ after bacterium injection. Furthermore, the removal of pollutants in the AIR treatments was higher than in the BD8 treatment without artificial aeration (Table 1), indicating that aerobic conditions are beneficial for wastewater purification (Chen et al. 2017). Similar to the results of Lu et al. (2012) and Liu et al. (2017), our experiment also suggested that the IBL treatment reduced water purification efficiency and even aggravated water pollution. The total number of viable bacteria in BD7, BD8 and BD9 treatments on Day 25 was basically on the same order of magnitude, but there was a significant difference compared to that at the beginning of experiments (Fig. 2), which was also observed by Chen \& Hu (2011). The current study showed that BD8 could be regarded as an optimum concentration of B. subtilis D9, and aeration was beneficial for wastewater purification.

Moreover, in the AIR treatment, the final weight, weight gain, PWG, SGR
Table 4. In situ aquaculture pond water purification, reported as the removal $(\%)$ of nitrogenous pollutants on Day 25 (mean \pm SD). EM: commercial aquaculture water purification agent; BD8: inoculation levels of Bacillus subtilis D9 at $5.5 \times 10^{8} \mathrm{cfu} \mathrm{ml}^{-1}$. Within columns, means with the same superscript letters are not significantly different (Tukey's post hoc test, $\mathrm{p}>0.05$ )

\begin{tabular}{|lccccc|}
\hline Treatment & $\mathrm{NH}_{4}{ }^{+}-\mathrm{N}$ & $\mathrm{NO}_{3}{ }^{-}-\mathrm{N}$ & $\mathrm{TN}$ & $\mathrm{NO}_{2}{ }^{-}-\mathrm{N}$ & Turbidity \\
\hline Control & $24 \pm 0.6^{\mathrm{c}}$ & $28 \pm 0.2^{\mathrm{c}}$ & $30 \pm 0.1^{\mathrm{c}}$ & $11 \pm 0.5^{\mathrm{c}}$ & $31 \pm 0.4^{\mathrm{c}}$ \\
EM & $55 \pm 0.8^{\mathrm{b}}$ & $48 \pm 0.9^{\mathrm{b}}$ & $60 \pm 0.7^{\mathrm{b}}$ & $42 \pm 0.4^{\mathrm{b}}$ & $73 \pm 0.8^{\mathrm{b}}$ \\
$\mathrm{BD} 8$ & $81 \pm 0.7^{\mathrm{a}}$ & $87 \pm 1.2^{\mathrm{a}}$ & $91 \pm 1.3^{\mathrm{a}}$ & $62 \pm 0.6^{\mathrm{a}}$ & $86 \pm 0.9^{\mathrm{a}}$ \\
\hline
\end{tabular}

Table 3. Growth performance of grass carp challenged with Vibrio parahaemolyticus for 22 d. Data are means \pm SD. BD8: inoculation levels of Bacillus subtilis D9 at $5.5 \times 10^{8} \mathrm{cfu} \mathrm{ml}^{-1}$; AIR: BD8 under the aeration treatment; IBL: BD8 with an inactivated bacteria liquid; PWG: percentage of weight gain; SGR: specific growth rate; RPS: relative percentage of survival. Within columns, means with the same superscript letters are not significantly different (Tukey's post hoc test, $p>0.05$ )

\begin{tabular}{|lccccccc|}
\hline Treatment & $\begin{array}{c}\text { Initial } \\
\text { weight (g) }\end{array}$ & $\begin{array}{c}\text { Final } \\
\text { weight (g) }\end{array}$ & $\begin{array}{c}\text { Weight } \\
\text { gain (g) }\end{array}$ & $\begin{array}{c}\text { PWG } \\
(\%)\end{array}$ & $\begin{array}{c}\text { SGR } \\
(\%)\end{array}$ & $\begin{array}{c}\text { RPS } \\
(\%)\end{array}$ & $\begin{array}{c}\text { Vibrio } \\
\left(10^{2} \mathrm{cfu} \mathrm{ml}^{-1}\right)\end{array}$ \\
\hline Control & $15.64 \pm 0.10$ & $20.63 \pm 0.28^{\mathrm{c}}$ & $4.99 \pm 0.21^{\mathrm{c}}$ & $30.20 \pm 1.21^{\mathrm{c}}$ & $1.20 \pm 0.04^{\mathrm{c}}$ & 0 & $3.20 \pm 0.14^{\mathrm{c}}$ \\
BD8 & $15.36 \pm 0.11$ & $24.67 \pm 0.35^{\mathrm{b}}$ & $9.31 \pm 0.38^{\mathrm{b}}$ & $61.98 \pm 2.68^{\mathrm{b}}$ & $2.19 \pm 0.08^{\mathrm{b}}$ & $42.79 \pm 8.62^{\mathrm{b}}$ & $1.45 \pm 0.06^{\mathrm{b}}$ \\
AIR & $15.65 \pm 0.12$ & $32.56 \pm 0.58^{\mathrm{a}}$ & $16.91 \pm 0.48^{\mathrm{a}}$ & $108.02 \pm 2.48^{\mathrm{a}}$ & $3.50 \pm 0.30^{\mathrm{a}}$ & $80.10 \pm 4.31^{\mathrm{a}}$ & $0.50 \pm 0.02^{\mathrm{a}}$ \\
IBL & $15.51 \pm 0.20$ & $18.86 \pm 0.26^{\mathrm{c}}$ & $3.35 \pm 0.09^{\mathrm{bc}}$ & $21.62 \pm 0.52^{\mathrm{c}}$ & $0.89 \pm 0.02^{\mathrm{c}}$ & $-26.87 \pm 14.93^{\mathrm{c}}$ & $3.49 \pm 0.22^{\mathrm{c}}$ \\
\hline
\end{tabular}




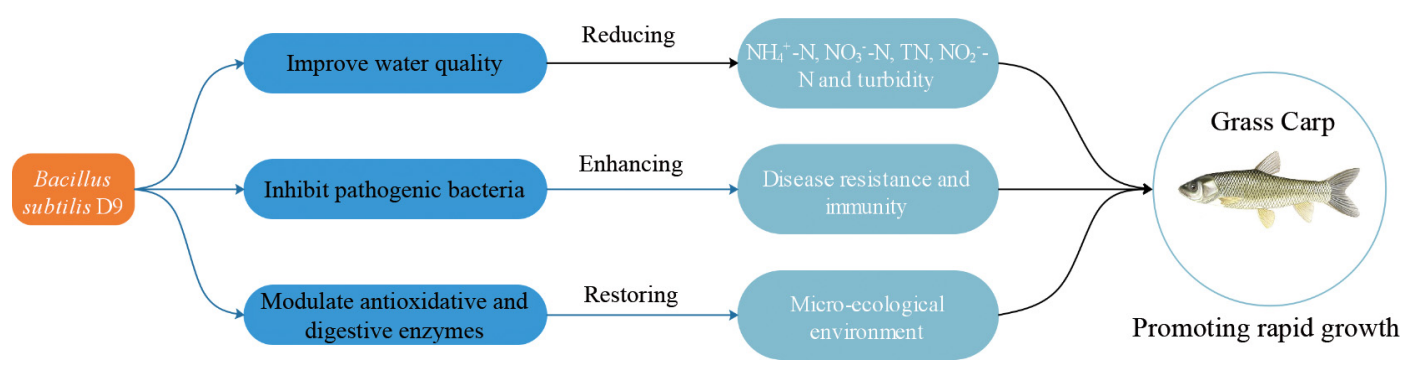

Fig. 4. Proposed mechanisms of Bacillus subtilis D9 affecting disease resistance of grass carp

tion of antioxidative and digestive enzymes, thus promoting the rapid growth of grass carp. On the other hand, probiotics produced by B. subtilis D9 effectively restore the micro-ecological environment and reduce the quantity of toxic materials, thus enhancing the disease resistance and immunity of grass carp.

\section{CONCLUSIONS}

Laboratory and in situ experiments showed that Bacillus subtilis D9 application significantly improved the quality of wastewater in terms of $\mathrm{NH}_{4}{ }^{+}-\mathrm{N}$, $\mathrm{NO}_{3}{ }^{-}-\mathrm{N}, \mathrm{TN}, \mathrm{NO}_{2}{ }^{-}-\mathrm{N}$ and turbidity. The optimum applied concentration was BD8 $\left(5.5 \times 10^{8} \mathrm{cfu} \mathrm{ml}^{-1}\right)$. We found significant differences among AIR, BD8, Control and IBL groups in PWG, SGR and RPS. We conclude that BD8 of B. subtilis D9 with aeration significantly improved water quality of the wastewater and increased the disease resistance of grass carp to Vibrio parahaemolyticus. Therefore, B. subtilis D9 could be used as a novel microbial agent with a great application potential in the aquaculture industry for wastewater purification and disease resistance.

Acknowledgements. This research was funded by the Major Science and Technology Program for Water Pollution Control and Treatment of China (2017ZX07108-001), the National Natural Science Foundation of China $(51779182,51979203)$, the Jiangsu Scientific Research Program (BE2017765), the Fundamental Research Funds for the Central Universities (2019B18314), the Science and Technology Project for Nanjing Water Conservancy Bureau (2019-208-6) and Melbourne Research Scholarship. We also thank the staff of Agricultural Sciences and Engineering College, Hohai University, for technical support during the experiments.

\section{LITERATURE CITED}

Ai Y, Zou Y, Tang W, Tian S and others (2013) Effects of microecologics on the growth profermance [sic], body composition and immunity activities of Misgurnus anguillicaudatus. Freshwat Fish 43:81-84
Akhter N, Wu B, Memon A, Mohsin M (2015) Probiotics and prebiotics associated with aquaculture: a review. Fish Shellfish Immunol 45:733-741

* Boopathy R, Kern C, Corbin A (2015) Use of Bacillus consortium in waste digestion and pathogen control in shrimp aquaculture. Int Biodeterior Biodegrad 102: 159-164

Chen L, Chang Y, Wang C, Shao X, Miao Q (2016) Biocontrol of the Fusarium wilt of Artemisia selengens [sic] seedling with bioorganic fertilizer of Bacillus subtilis D9. Nongye Ziyuan Yu Huanjing Xuebao 33:66-72

Chen L, Han R, Zhang H, Xu X and others (2017) Irrigatingcontinuous cropping with Bacillus subtilis D9 fortified waste water could control the Fusarium wilt of Artemisia selengens [sic]. Appl Soil Ecol 113:127-134

Chen S, Hu Y (2011) Use of Bacillus subtilis in purification of slightly-polluted water. Acta Sci Circumst 31:1594-1601

Cho JY, Jung HY, Kim JK (2019) Biodegraded mackerel wastewater selectively inhibits harmful algal blooms. J Hazard Mater 364:349-355

Di Trapani AM, Sgroi F, Testa R, Tudisca S (2014) Economic comparison between offshore and inshore aquaculture production systems of European sea bass in Italy. Aquaculture 434:334-339

Ding XL, Wang Z, Chen W (2012) Isolation, identification and water purification effect of Bacillus subtilis WH-5. Hunan Nongye Kexue 1:15-19

Dong H, Jiang J, Zheng L, Pang J (2010) Research advances of novel microecologic probiotics Bacillus coagulans. Shipin Kexue 1:274-286

Ferreira JG, Saurel C, Lencart e Silva JD, Nunes JP, Vazquez F (2014) Modelling of interactions between inshore and offshore aquaculture. Aquaculture 426-427: 154-164

Gelfand I, Barak Y, Even-Chen Z, Cytryn E, Van Rijn J, Krom MD, Neori A (2003) A novel zero discharge intensive seawater recirculating system for the culture of marine fish. J World Aquaculture Soc 34:344-358

Hao K, Liu J, Ling F, Liu X, Lu L, Xia L, Wang G (2014) Effects of dietary administration of Shewanella haliotis D4, Bacillus cereus D7 and Aeromonas bivalvium D15, single or combined, on the growth, innate immunity and disease resistance of shrimp, Litopenaeus vannamei. Aquaculture 428-429:141-149

* He Y, Biswarup Y, Hao S, Li J, Zhang Y (2019) Storm runoff differentially influences the nutrient concentrations and microbial contamination at two distinct beaches in northern China. Sci Total Environ 663:400-407

*Hlongwane GN, Sekoai PT, Meyyappan M, Moothi K (2019) Simultaneous removal of pollutants from water using 
nanoparticles: a shift from single pollutant control to multiple pollutant control. Sci Total Environ 656:808-833

Hossain MM, Begum M, Kim I (2015) Effect of Bacillus subtilis, Clostridium butyricum and Lactobacillus acidophilus endospores on growth performance, nutrient digestibility, meat quality, relative organ weight, microbial shedding and excreta noxious gas emission in broilers. Vet Med 60:77-86

$\mathrm{Hu}$ YW, Wu B, Chen ZQ (2015) Active monitoring and risk analysis of pathogenic Vibrio in aquaculture fish. Chin J Health Lab Technol 21:3726-3730

Kijjoa A, Sawang WP, Hu YW (2004) Drugs and cosmetics from the sea. Mar Drugs 2:73-82

Kuebutornye FKA, Abarike DE, Lu Y (2019) A review on the application of Bacillus as probiotics in aquaculture. Fish Shellfish Immunol 87:820-828

Lee SH, Ingale SL, Kim JS, Kim KH and others (2014) Effects of dietary supplementation with Bacillus subtilis LS 1-2 fermentation biomass on growth performance, nutrient digestibility, cecal microbiota and intestinal morphology of weanling pig. Anim Feed Sci Technol 188:102-110

Li R, Xue C, Zhao J, Su Y (2009) Nitrogen removal from wastewater by four species of immobilized algae. Chin J Environ Eng 24:14-26

Liu H, Wang S, Cai Y, Guo X and others (2017) Dietary administration of Bacillus subtilis HAINUP40 enhances growth, digestive enzyme activities, innate immune responses and disease resistance of tilapia, Oreochromis niloticus. Fish Shellfish Immunol 60:326-333

Liu KF, Chiu CH, Shiu YL (2010) Effects of the probiotic, Bacillus subtilis E20, on the survival, development, stress tolerance, and immune status of white shrimp, Litopenaeus vannamei larvae. Fish Shellfish Immunol 28:837-844

Ku L, Tan H, Luo G, Liang W (2012) The effects of Bacillus subtilis on nitrogen recycling from aquaculture solid waste using heterotrophic nitrogen assimilation in sequencing batch reactors. Bioresour Technol 124: 180-185

Lu Z, Guo W, Liu C (2018) Isolation, identification and characterization of novel Bacillus subtilis. J Vet Med Sci 80: 427-433

Lulijwa R, Rupia EJ, Alfaro AC (2019) Antibiotic use in aquaculture, policies and regulation, health and environmental risks: a review of the top 15 major producers. Rev Aquacult 23:156-162

Marinho-Soriano E, Azevedo CAA, Trigueiro TG, Pereira DC, Carneiro MAA, Camara MR (2011) Bioremediation of aquaculture wastewater using macroalgae and Artemia. Int Biodeterior Biodegradation 65:253-257

Editorial responsibility: Catriona MacLeod,

Hobart, Tasmania, Australia

Reviewed by: F. Han and 2 anonymous referees
Martínez Cruz P, Ibáñez AL, Monroy Hermosillo OA, Ramírez Saad HC (2012) Use of probiotics in aquaculture. ISRN Microbiol 2012:916845

* Oliveira J, Castilho F, Cunha A, Pereira MJ (2012) Bacteriophage therapy as a bacterial control strategy in aquaculture. Aquacult Int 20:879-910

* Pepi M, Borra M, Tamburrino S, Saggiomo M and others (2016) A Bacillus sp. isolated from sediments of the Sarno River mouth, Gulf of Naples (Italy) produces a biofilm biosorbing $\mathrm{Pb}(\mathrm{II})$. Sci Total Environ 562:588-595

Shao NL, Guo Y, Shen H, Chen J, Wei H (2016) The effects of Bacillus subtilis and Ipomoea aquatica Forsk on water quality in the pond for co-farming of rice-crayfish-finless eel. J Shanghai Ocean University 25(3):415-421

* Shao Y, Zhong H, Mao X, Zhang H (2020) Biochar-immobilized Sphingomonas sp. and Acinetobacter sp. isolates to enhance nutrient removal: potential application in crab aquaculture. Aquacult Environ Interact 12:251-262

Shen BQ, Chen JM, Guo JL, Pan Q, Sun LH (2013) Effect of adding Bacillus subtilis to diets on growth performance, digestive enzymes activity and body composition of fingerling black carp (Mylopharyngodon piceus). Shui Sheng Sheng Wu Hsueh Bao 37:48-53

* Subtil EL, Silva MV, Lotto BA, Moretto MRD, Mierzwa JC (2019) Pilot-scale investigation on the feasibility of simultaneous nitrification and denitrification (SND) in a continuous flow single-stage membrane bioreactor. J Water Process Eng 32:100995

Wang L, Shao X, Xu M, Chen S (2019) Bioremediation of nitrogen- and phosphorus-polluted aquaculture sediment by utilizing combined immobilized effective microorganisms and sediment aeration technology. Int J Agric Biol Eng 12:192-201

Yang Y, Wang W, Deng H, Hao S (2012) Purification of eutrophic water with Bacillus subtilis and Scindapsus aureus. Zhongguo Nongxue Tongbao 27:34-56

Yu AP (2015) Study on probiotics and its application in aquaculture. China Aquacult 12:76-78

* Yun L, Yu Z, Li Y, Luo P, Jiang X, Tian Y, Ding X (2019) Ammonia nitrogen and nitrite removal by a heterotrophic Sphingomonas sp. strain LPN080 and its potential application in aquaculture. Aquaculture 500:477-484

Zar JH (2010) Biostatistical analysis. Q Rev Biol 18:797-809 * Zokaeifar H, Babaei N, Saad CR, Kamarudin MS, Sijam K, Balcazar JL (2014) Administration of Bacillus subtilis strains in the rearing water enhances the water quality, growth performance, immune response, and resistance against Vibrio harveyi infection in juvenile white shrimp, Litopenaeus vannamei. Fish Shellfish Immunol 36:68-74

Submitted: October 5, 2020

Accepted: May 3, 2021

Proofs received from author(s): July 4, 2021 